\title{
INTRODUCTION OF ENVIRONMENT MANAGEMENT KNOWLEDGE AREA IN PMBOK (PROJECT MANAGEMENT BODY OF KNOWLEDGE): A PRELIMINARY STUDY
}

\author{
Manuj Madan \\ Alok Sahai ${ }^{2}$ iD
}

Received: June 20, 2019 / Revised: July 15, 2019/ Accepted: October 15, 2019

(C) Association of Economists and Managers of the Balkans, 2019

\begin{abstract}
The objective of this study is to know the perception of varied experienced project management professionals of India to measurement-based and valuation-based methods for inclusion in the imaginary environment management knowledge area of PMBOK. Results attained through SPSS using chi-square test of association conclude that there is a significant relationship between experience and choosing the right method. The current study suggests that lifecycle analysis and ecosystem service valuation should be included in the environment management knowledge area of $P M B O K$.
\end{abstract}

Keywords: Project Management Body of Knowledge, Environment Management, Work Experience

JEL Classifications M19 $\cdot$ Q51 $\cdot$ Q01

This paper was presented at the Fifth International Scientific Conference on Knowledge Based Sustainable Development - ERAZ 2019 - May 23, Budapest, Hungary, www.eraz.org.rs

Manuj Madan

manuj.madan@chitkara.edu.in

Chitkara University, Chandigarh-Patiala NH-64, Rajpura - 140401, India

Sri Sri University, Cuttack, Odisha - 754006, India 


\section{INTRODUCTION}

After defining ten knowledge areas, namely cost management, scope management, integration management, time management, quality management, resource management, communications management, risk management, procurement management and stakeholder management by Project Management Body of Knowledge (PMBOK), the work of project managers and other stakeholders became more organized and visible. Many projects were implemented by dividing work structures according to these knowledge areas, but there was not much consideration given to sustainability effects of the project. There is no knowledge area that takes care of environmental effects of a project. It was, thus, identified as a visible gap in research to introduce a framework of environment management as an $11^{\text {th }}$ knowledge area in PMBOK.

Sustainability actually has three pillars - environment, economic and social. We shall be focussing mainly on inter-relationship of project management with environment management. Various measurement-based methods and valuation-based methods exist for environment management. Four methods in measurement-based approach, namely carbon footprint, balanced scorecard, ecological footprint and life cycle analysis and four methods in valuation-based approach, namely cost benefit analysis, ecosystem service valuation, sustainability value added and triple bottom line have been chosen for this study. The criteria for choosing these four in each approach were popularity on online search engines.

Each project manager with different experience level, which was identified through number of projects completed by them, and through different age groups, have varied perception about different methods to be given priority for inclusion in new knowledge area of project management. The understanding of the perception of project managers for inclusion of environmental factors in PMBOK is the crux of the issue.

Over a couple of decades, there have been lot of word about keeping environment safe for future generations. This has resulted into introduction of sustainable techniques in project management. Also, sustainable operations have been the talk of many researchers. But to my surprise, there has been no knowledge area in Project Management Body of Knowledge (PMBOK) guide that talks about sustainability, specifically environmental aspects of sustainability. The research gap was, therefore, found to introduce a framework of environment management knowledge area in PMBOK. The perception of various project managers was studied in this regard to identify methods that can be given priority in this new knowledge area of environment management. Some of the existing literature that throws light on some aspects of similar research in their studies are mentioned below:

Labuschagne and Brent (2004), introduced a procedure to improve the consideration of environmental aspects in project life cycle management in the process industry of South Africa. Furthermore, a qualitative procedure to evaluate the environmental factors of a project was demonstrated in order to provide the decision-makers at the phase-end reviews with the relevant information.

It has been established by Labuschagne and Brent (2005), that the asset life cycle resulting from the project, and the subsequent product life cycle resulting from the asset have economic, social and environmental consequences, which are in turn associated with an implemented project. This research developed a framework to assess the sustainability of operational activities. 
Brent and Peterick (2007), have suggested that EIA (Environmental Impact assessment) may commence in any of the project lifecycle phases, from pre-feasibility to detailed design. This research proposed a model for the process industry in the energy sector to align the new South African EIA process with the project lifecycles and to provide EIA stage-gate criteria.

A study by Mathur, Price and Austin (2008), shows that sustainability assessment process, if appropriately designed could be the ideal process through which the benefits of stakeholder engagement within a project can be maximized and the sustainability agenda be pursued.

In construction industry as per Fernández-Sánchez and Rodríguez-López (2010), energy consumption, waste management and ecological footprint are found to be the most important indicators of sustainability.

Robichaud and Anantatmula (2011) showed that greening project management practices can provide a significant value to a sustainable construction project while delivering it within acceptable cost constraints.

A framework has been proposed by Talbot and Ray Venkataraman (2011) that produced a more manageable set of 27 high level indicators, not all of which will be applicable to all projects. The utility of the proposed framework and indicator set has been back checked against a recently completed engineer, procure, and construction (EPC) managed mining project undertaken by a large engineering and project management services organization.

Brones, Marly and Zancul (2014) have discussed the issues related to environmental product development and environmental sustainability and explored the points of intersection between eco-design and project management.

Sanchez (2014) has proposed that there is a good potential for integrating sustainability and project management in operational terms.

Martens and Carvalho (2016) have suggested that though firms have concern about sustainability in project management, there is a gap between the perception of importance and the actual use in practice.

\section{METHODOLOGY}

\subsection{Research Questions and Hypotheses Formulation}

As mentioned above, the goal of the current research is to investigate the significant differences in the perception of project managers towards environmental sustainability in project management. The knowledge areas in project management body of knowledge (PMBOK) were considered as a standard reference for this research. The independent variables were number of projects completed by the project manager in his lifetime so far, which was categorized as less than or equal to 15 projects completed and greater than 15 projects completed. The age group of project manager was another independent variable categorized as less than 34 years, between $34 \& 44$ and more than 44 years of age. The researchers sought to answer the following research questions through this study:

Research Question One: Which is the most widely accepted valuation-based method for inclusion in framework of environment management knowledge area? 
Research Question Two: Which is the most widely accepted measurement-based method for inclusion in framework of environment management knowledge area?

Research Question Three: What is the effect of different experience levels of project managers on choosing the appropriate methods for framework of new knowledge area in project management?

To validate the results of study, the following hypothesis have been formulated:

Null Hypothesis One: The varied experience level has no effect on choosing the right valuation-based method for developing framework of environment management knowledge area in PMBOK.

Alternate Hypothesis One: The varied experience level has effect on choosing the right valuation-based method for developing framework of environment management knowledge area in PMBOK.

Null Hypothesis Two: The varied experience level has no effect on choosing the right measurement-based method for developing framework of environment management knowledge area in PMBOK.

Alternate Hypothesis Two: The varied experience level has effect on choosing the right measurement-based method for developing framework of environment management knowledge area in PMBOK.

\subsection{Data Collection}

The present study is based on both primary and secondary data. The primary data have been collected from project managers selected by judgement sampling with the help of pre-structured questionnaire. After the examination of 500 complete questionnaire, further analysis was carried out. Secondary data has been extracted from research studies and articles published in journals. The PMBOK guide was also used as a source of secondary data.

\section{DATA AND ANALYSIS}

The collected data were analysed through chi-square test of association and multinomial regression using SPSS version 26. Additionally, correspondence analysis was also done. The analysis is in conformity with the objectives of study and the hypotheses formulated.

Bar chart in Chart 1 shows that ecosystem service valuation method is the most preferred method by project management professionals for introduction in environment management knowledge area, which answers Research Question One. The cross tabulation and results with p-value less than 0.05 are shown in table 1 and table 2 respectively. The test was significant and so we reject NULL hypothesis (NULL Hypothesis One) and accept the alternate hypothesis (Alternate Hypothesis One)

Correspondence analysis as shown in figure 1 does not give a clear clustering information about which age groups prefer which type of valuation method. 
Further in table 3, multicollinearity is tested, which gives all VIF (Variance Inflation Factor) as less than 5 and so our assumption for multinomial regression is satisfied. Also, there were no outliers detected in the given valuation method data, which were tested by means of running binary logistic regression after creating dummy variables. The likelihood ratio test gives p-value less than 0.05 as shown in table 4 . The running of multinomial logistic regression in SPSS gives a multinomial model for valuation methods as shown in table 5 with intercept as 75.627 and coefficients of age-group as 85.473 and of experience as 85.155 .

Table 1. Cross tabulation for valuation-based measurements

\begin{tabular}{|c|c|c|c|c|c|c|}
\hline \multicolumn{7}{|c|}{ experience * valuation_method Crosstabulation } \\
\hline & & \multicolumn{4}{|c|}{ valuation_method } & \multirow[b]{2}{*}{ Total } \\
\hline & & $\begin{array}{l}\text { cost benefit } \\
\text { analysis }\end{array}$ & $\begin{array}{l}\text { ecosystem } \\
\text { service } \\
\text { valuation }\end{array}$ & $\begin{array}{l}\text { sustainability } \\
\text { value added }\end{array}$ & $\begin{array}{c}\text { triple bottom } \\
\text { line }\end{array}$ & \\
\hline \multirow{2}{*}{$\begin{array}{l}\text { less than or } \\
\text { equal to } 15 \\
\text { projects }\end{array}$} & Count & 117 & 129 & 69 & 15 & 330 \\
\hline & $\begin{array}{l}\text { Expected } \\
\text { Count }\end{array}$ & 107.6 & 141.2 & 61.4 & 19.8 & 330.0 \\
\hline \multirow{2}{*}{$\begin{array}{l}\text { greater than } 15 \\
\text { projects }\end{array}$} & Count & 46 & 85 & 24 & 15 & 170 \\
\hline & $\begin{array}{l}\text { Expected } \\
\text { Count }\end{array}$ & 55.4 & 72.8 & 31.6 & 10.2 & 170.0 \\
\hline \multirow[t]{2}{*}{ Total } & Count & 163 & 214 & 93 & 30 & 500 \\
\hline & $\begin{array}{l}\text { Expected } \\
\text { Count }\end{array}$ & 163.0 & 214.0 & 93.0 & 30.0 & 500.0 \\
\hline
\end{tabular}

Table 2. Chi square test results for valuation-based methods

\begin{tabular}{|l|c|c|c|}
\hline & Value & Df & $\begin{array}{c}\text { Asymptotic } \\
\text { Significance } \\
\text { (2-sided) }\end{array}$ \\
\hline Pearson Chi-Square & $11.751^{\text {a }}$ & 3 & .008 \\
\hline Likelihood Ratio & 11.702 & 3 & .008 \\
\hline Linear-by-Linear Association & 1.538 & 1 & .215 \\
\hline N of Valid Cases & 500 & & \\
\hline a. 0 cells $(0.0 \%)$ have expected count less than 5. The minimum expected count is 10.20. \\
\hline
\end{tabular}




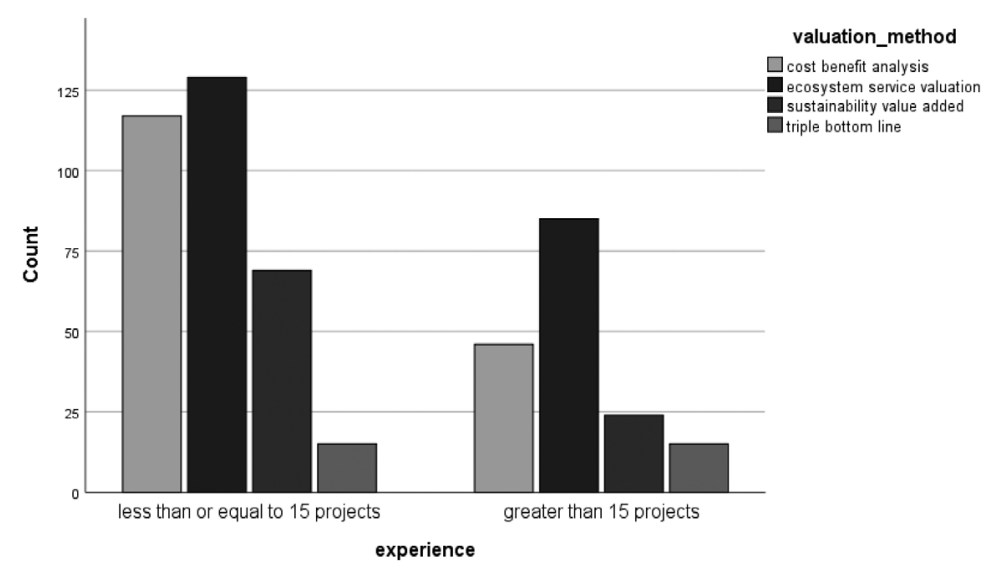

Chart 1. Bar chart for valuation-based method showing preference for ecosystem service valuation approach

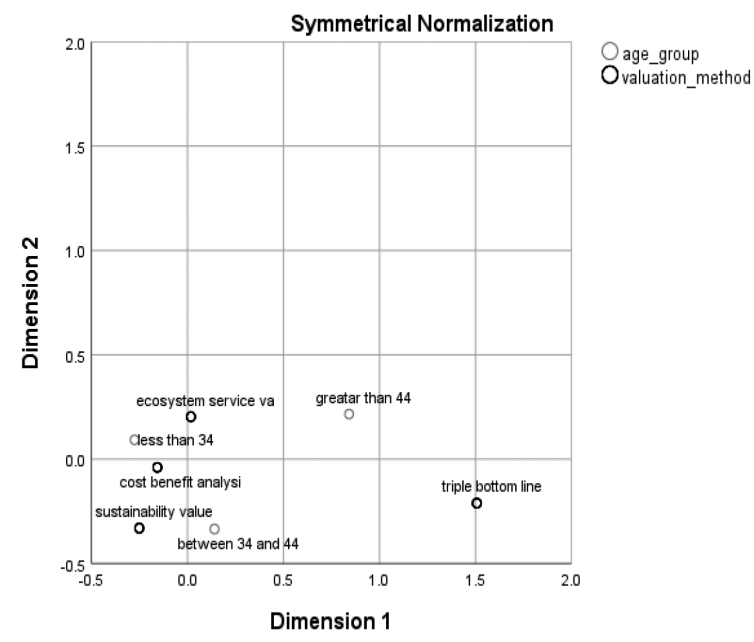

Figure 1. Correspondence analysis biplot for age groups and valuation methods

Table 3. Multicollinearity test for valuation-based methods

\begin{tabular}{|l|l|r|r|}
\hline \multicolumn{3}{|c|}{ Coefficients $^{\mathbf{a}}$} \\
\cline { 3 - 4 } Model & \multicolumn{2}{|c|}{ Collinearity Statistics } \\
\cline { 3 - 4 } 1 & less 34 & .483 & VIF \\
\cline { 2 - 4 } & between 34 and 44 & .480 & 2.072 \\
\cline { 2 - 4 } & less than equal 15 & .968 & 1.034 \\
\hline \multicolumn{2}{|l|}{ a. Dependent Variable: valuation_method } & \multicolumn{2}{l}{} \\
\hline
\end{tabular}


Table 4. Likelihood ratio tests showing model fitting information for valuation methods

\begin{tabular}{|l|r|r|r|r|}
\hline \multicolumn{7}{|c|}{ Model Fitting Information } \\
\hline \multirow{2}{*}{ Model } & Model Fitting Criteria & \multicolumn{3}{|c|}{ Likelihood Ratio Tests } \\
\cline { 2 - 5 } & -2 Log Likelihood & Chi-Square & df & Sig. \\
\hline Intercept Only & 97.175 & & & 9 \\
\hline Final & 75.627 & 21.548 & 9 & .010 \\
\hline
\end{tabular}

Table 5. Model from multinomial regression with valuation methods as dependent variable

\begin{tabular}{|c|c|c|c|c|}
\hline \multicolumn{5}{|c|}{ Likelihood Ratio Tests } \\
\hline \multirow[b]{2}{*}{ Effect } & Model Fitting Criteria & \multicolumn{3}{|c|}{ Likelihood Ratio Tests } \\
\hline & $\begin{array}{l}-2 \text { Log Likelihood of } \\
\text { Reduced Model }\end{array}$ & Chi-Square & df & Sig. \\
\hline Intercept & $75.627^{\mathrm{a}}$ & .000 & 0 & \\
\hline age_group & 85.473 & 9.846 & 6 & .131 \\
\hline experience & 85.155 & 9.527 & 3 & .023 \\
\hline \multicolumn{5}{|c|}{$\begin{array}{l}\text { The chi-square statistic is the difference in }-2 \text { log-likelihoods between the final model and a reduced } \\
\text { model. The reduced model is formed by omitting an effect from the final model. The null hypothesis is that } \\
\text { all parameters of that effect are } 0 \text {. }\end{array}$} \\
\hline
\end{tabular}

A similar series of tests on measurement-based methods were performed with results as shown in tables 6 to table 10. The final model for measurement methods as shown in table 10 has intercept as 94.223 and coefficients of age-group as 109.530 and coefficient of experience as 121.286. The bar chart in Chart 2 shows preference for life cycle analysis approach.

As shown in figure 2, there is additional result in the form of clusters through correspondence analysis run on measurement-based method and age groups.

Table 6. Chi Square test between measurement-based method and number of projects completed as two categorical variables

\begin{tabular}{|l|r|r|r|}
\hline \multicolumn{2}{|c|}{ Chi-Square Tests } \\
\hline & Value & df & $\begin{array}{c}\text { Asymptotic } \\
\text { Significance (2-sided) }\end{array}$ \\
\hline Pearson Chi-Square & $14.659^{\mathrm{a}}$ & 3 & .002 \\
\hline Likelihood Ratio & 14.866 & 3 & .002 \\
\hline $\begin{array}{l}\text { Linear-by-Linear } \\
\text { Association }\end{array}$ & 12.666 & 1 & .000 \\
\hline N of Valid Cases & 500 & & \\
\hline a. 0 cells (0.0\%) have expected count less than 5. The minimum expected count is 28.56. \\
\hline
\end{tabular}


Table 7. Cross tabulation for measurement-based methods

\section{experience * measurement_method Crosstabulation}

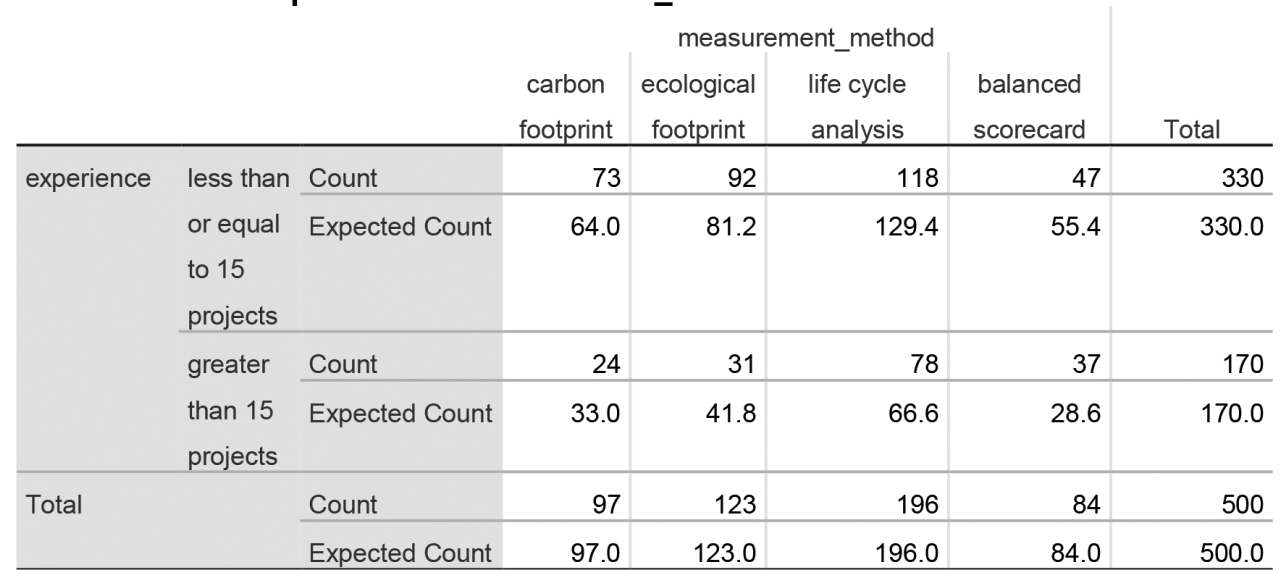

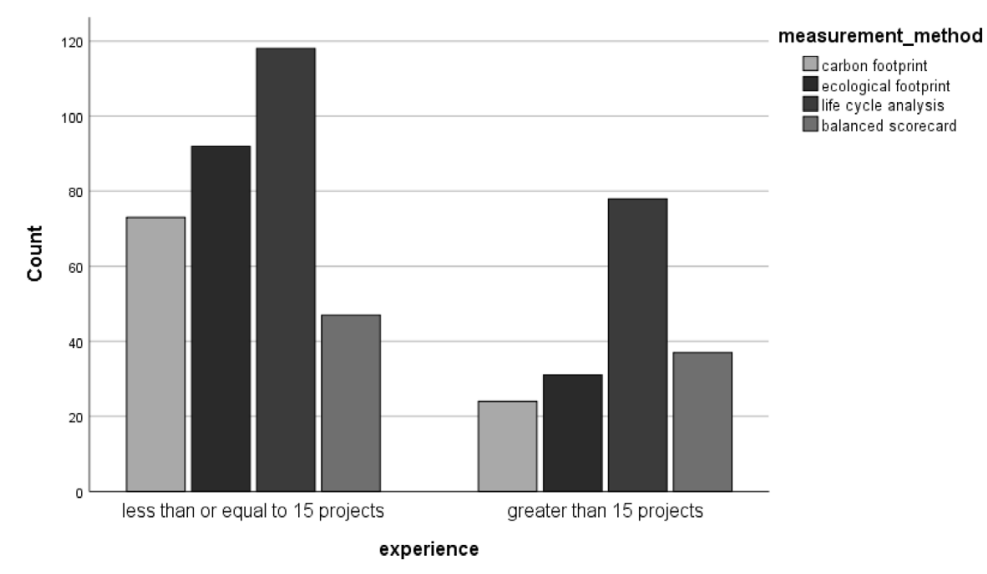

Chart 2. Bar chart for measurement-based method showing preference for life cycle analysis approach

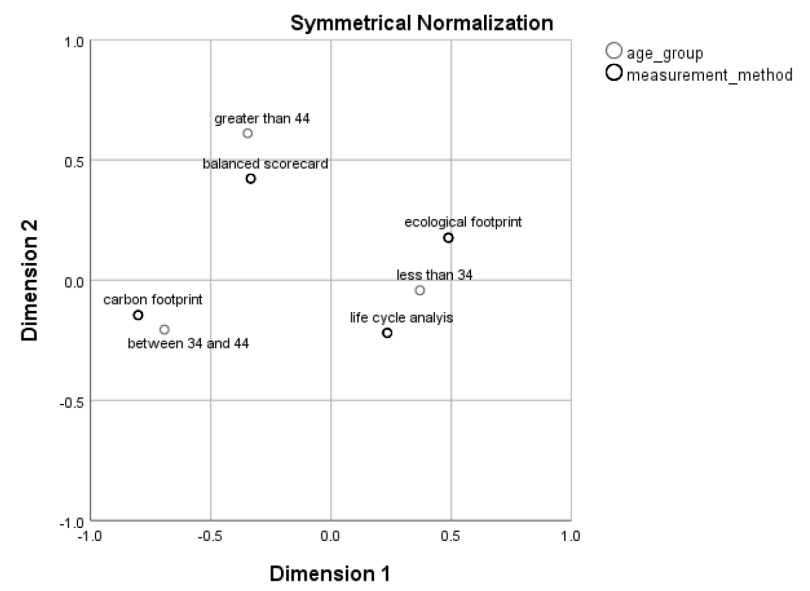

Figure 2. Correspondence analysis biplot for age groups and measurement-based methods 
Table 8. Multicollinearity test results for measurement-based methods

\begin{tabular}{|c|c|c|c|}
\hline \multicolumn{4}{|c|}{ Coefficients $^{\mathrm{a}}$} \\
\hline \multirow{2}{*}{\multicolumn{2}{|c|}{ Model }} & \multicolumn{2}{|c|}{ Collinearity Statistics } \\
\hline & & Tolerance & VIF \\
\hline \multirow{3}{*}{1} & Less34 & .441 & 2.268 \\
\hline & between 34 and 44 & .438 & 2.284 \\
\hline & less than 15 projects & .971 & 1.030 \\
\hline
\end{tabular}

Table 9. Likelihood ratio tests showing model fitting information for measurement methods

\begin{tabular}{|l|r|r|r|r|}
\hline \multicolumn{5}{|c|}{ Model Fitting Information } \\
\hline \multirow{3}{*}{ Model } & Model Fitting Criteria & \multicolumn{3}{|c|}{ Likelihood Ratio Tests } \\
\cline { 2 - 5 } & -2 Log Likelihood & Chi-Square & df & Sig. \\
\hline Intercept Only & 136.151 & & & 9 \\
\hline Final & 94.223 & 41.929 & & .000 \\
\hline
\end{tabular}

Table 10. Model from multinomial regression with measurement methods as dependent variable

\begin{tabular}{|l|r|r|r|r|}
\hline \multicolumn{5}{|c|}{ Likelihood Ratio Tests } \\
\hline \multirow{3}{*}{ Effect } & Model Fitting Criteria & \multicolumn{2}{|c|}{ Likelihood Ratio Tests } \\
\cline { 2 - 5 } & $\begin{array}{c}-2 \text { Log Likelihood of } \\
\text { Reduced Model }\end{array}$ & \multicolumn{1}{c|}{ Chi-Square } & df & \multicolumn{2}{|c|}{ Sig. } \\
\hline Intercept & $94.223^{\mathrm{a}}$ & .000 & 0 & .002 \\
\hline experience & 109.530 & 15.307 & 3 & .000 \\
\hline age_group & 121.286 & 27.063 & 6 & \\
\hline
\end{tabular}

The chi-square statistic is the difference in -2 log-likelihoods between the final model and a reduced model. The reduced model is formed by omitting an effect from the final model. The null hypothesis is that all parameters of that effect are 0 .

a. This reduced model is equivalent to the final model because omitting the effect does not increase the degrees of freedom.

\section{FUTURE RESEARCH DIRECTIONS}

Similar further studies can be carried for impact on internal stakeholders by introduction of social impact factors in the project management body of knowledge.

\section{CONCLUSION}

The chi square test of association between categorical variables of valuation method (four categories) and experience in form of number of projects completed (two categories) was run in SPSS version 26 i.e. the varied experience level has effect on choosing the right valuation-based method for developing framework of environment management knowledge area in PMBOK. A similar series of tests on measurement-based methods were performed in which we conclude that varied experience level has effect on choosing the right measurement-based method.

There is an interesting conclusion in the form of biplot that greater than 44 age project managers prefer to include balanced scorecard approach, those between 34 and 44 prefer carbon footprint and less than 34 age project managers prefer ecological footprint and lifecycle analysis approaches for inclusion in environment management knowledge area. However, no such clusters were ob- 
served in case of biplot in valuation-based method resulting in no preference by project managers of different age groups towards specific valuation-based method.

\section{ACKNOWLEDGEMENTS}

This research was the result of motivation by Prof. (Dr.) Srinivas Subbarao Pasumarti, Dean FCMS, Sri Sri University. I am also indebted to Dr. Sandhir Sharma, Dean, Chitkara Business School, Chitkara University for providing moral support in conducting this research for my doctoral studies.

\section{REFERENCES}

Brent, A. C., Petrick, W. (2007) Environmental impact assessment during project execution phases: towards a stage-gate project management model for the raw materials processing industry of the energy sector, Impact Assessment and Project Appraisal, 25(2), 111-122. https://doi.org/10.3152/146155107X205832

Brones, F., Marly, Carvalho Monteiro de, Zancul, Eduardo de Senzi (2014) Eco-design in project management: A missing link for the integration of sustainability in product development, Journal of Cleaner Production, 1-36. https://doi.org/10.1016/j.jclepro.2014.05.088

Fernandez-Sanchez, G.R., Rodríguez-López, F. (2010) A methodology to identify sustainability indicators in construction project management-Application to infrastructure projects in Spain, Ecological Indicators, 10, 1193-1201. https://doi.org/10.1016/j.ecolind.2010.04.009

Labuschagne, C., Brent, A. C. (2005) Sustainable Project Life Cycle Management: the need to integrate life cycles in the manufacturing sector, International journal of project management, 23, 159-168. https://doi.org/10.1016/j.ijproman.2004.06.003

Labuschagne, C., Brent, A.C. (2004) Sustainable project life cycle management: aligning project management methodologies with the principles of sustainable development, paper presented at Global Knowledge for Project Management Professionals, May 2004, Gallagher Estate, Johannesburg, PMSA (Project Management South Africa).

Mathur, V. N., Price, Andrew D.F., Austin, S. (2008) Conceptualizing stakeholder engagement in the context of sustainability and its assessment, Construction Management and Economics, 26(6), 601-609. https://doi.org/10.1080/01446190802061233

Martens, M.L., Carvalho, M.M. (2016) The Challenge of Introducing Sustainability into Project Management Function: Multiple-Case Studies, Journal of Cleaner Production, 12-39. https://doi.org/10.1016/j.jclepro.2015.12.039

Robichaud, L.B., Anantatmula, V.S. (2011) Greening Project Management Practices for Sustainable Construction, Journal of management in engineering,27(1), 48-57. https://doi.org/10.1061/(ASCE)ME.1943-5479.0000030

Sánchez, Marisa Analía, (2014) Integrating sustainability issues into project management, Journal of Cleaner Production, 1 -12. https://doi.org/10.1016/j.jclepro.2013.12.087

Talbot, J., Ray Venkataraman, R. (2011) Integration of Sustainability Principles into Project Baselines Using A Comprehensive Indicator Set, International Business \& Economics Research Journal, 10(9), 29-40. https://doi.org/10.19030/iber.v10i9.5624

\section{ADDITIONAL READING}

A Guide to the Project Management Body of Knowledge, $5^{\text {th }}$ edition, Newtown Square, Pennsylvania, Project Management Institute, Inc.

Sankar, Ajith, R.N., (2015) Environmental Management, Jai Singh Road, New Delhi, Oxford University Press. 